\begin{tabular}{cc|c}
\hline Tar. Bil. Der. & Journal of Agricultural Sciences \\
& $\begin{array}{c}\text { Dergi web sayfası: } \\
\text { www.agri.ankara.edu.tr/dergi }\end{array}$ & Journal homepage: \\
& www.agri.ankara.edu.tr/journal
\end{tabular}

\title{
Agro-Morphological Variation Among an Ancient World Barley Collection
}

\author{
Alptekin KARAGÖZ ${ }^{\mathrm{a}}$, Kürşad ÖZBEK ${ }^{\mathrm{b}}$, Taner AKAR ${ }^{\mathrm{c}}$, Namuk ERGÜN ${ }^{\mathrm{b}}$, Sinan AYDOĞAN ${ }^{\mathrm{b}}$, İsmail \\ SAYIM $^{\mathrm{b}}$ \\ ${ }^{a}$ Aksaray University, Vocational School for Technical Sciences, Aksaray, TURKEY \\ ${ }^{b}$ Central Research Institute for Field Crops, Ankara, TURKEY \\ ${ }^{c}$ Akdeniz University, Faculty of Agriculture, Department of Field Crops, Antalya, TURKEY
}

\section{ARTICLE INFO}

Research Article $\quad$ DOI: 10.15832/ankutbd.385860

Corresponding Author: Alptekin KARAGÖZ, E-mail: akaragoz@aksaray.edu.tr, Tel: +90 (532) 4040467

Received: 20 December 2014, Received in Revised Form: 22 February 2016, Accepted: 29 February 2016

\begin{abstract}
Historically barley has been a very important crop in agriculture system of Turkey as it is now. Barley breeding and collecting activities started at the beginning of $20^{\text {th }}$ century in Turkey. During that time huge amount of material piled up at the seed banks and collections of plant breeding institutions through collecting missions and material exchange. We characterized around 3.500 barley accessions of Eskisehir Transition Zone Agricultural Research Institute. Characterized populations have been obtained from 44 countries (Asia 14, Europe 19, Americas 6, Africa 4 and Australia) of 5 continents and two international agricultural research institutes since 1950's up to date. We are presenting only the result of 2.517 two row barley accessions with this paper. Results of the study reveal a series of phenotypic similarities and differences between the materials of several countries. Results also show the existence of a significant amount of diversity between the populations which can be used as a source for breeding programs.
\end{abstract}

Keywords: Barley; Hordeum vulgare L.; Landrace; Turkey; Characterization; Variation

\section{Eski Bir Arpa Koleksiyonundaki Fenotipik Varyasyon}

\section{ESER BILLGISI}

Araştırma Makalesi

Sorumlu Yazar: Alptekin KARAGÖZ, E-posta: akaragoz@aksaray.edu.tr, Tel: +90 (532) 4040467

Geliş Tarihi: 20 Aralık 2014, Düzeltmelerin Gelişi: 22 Şubat 2016, Kabul: 29 Şubat 2016

\section{ÖZET}

Arpa, günümüzde olduğu gibi geçmişte de Türkiye'nin tarım sistemi içinde önemli bir yere sahip olmuştur. Türkiye'de arpa ıslah ve toplama çalışmaları XX. yüzyılın ilk dönemlerinde başlamıştır. $O$ günden günümüze değin toplama çalışmaları ve materyal değişimi yoluyla tohum bankalarında ve bitki ıslahı yapan enstitülerin koleksiyonlarında çok sayıda arpa örneği birikmiştir. Bu çalışmada Eskişehir Geçit Kuşă̆ı Tarımsal Araştırma Enstitüsü stoklarındaki 3.500 civarında arpa örnekleri kullanılmıştır. Araştırma materyali 1950 yılından günümüze kadar dünyanın 5 kıtasındaki 44 
ülkeden (Asya 14, Avrupa 19, Amerika 6, Afrika 4 ve Avustralya) ve iki uluslararası tarımsal araştırma enstitüsünden temin edilmiştir. Burada sadece 2 sıralı arpaların yer aldığı 2.517 örneğe ait sonuçlar verilmiştir. Çalışma sonuçlarına göre, örnekler arasında arpa ıslah programlarına iyi bir kaynak oluşturabilecek önemli derecede çeşitlilik olduğunu belirlenmiştir.

Anahtar Kelimeler: Arpa; Hordeum vulgare L.; Yerel çeşit; Türkiye; Karakterizasyon; Çeşitlilik

(C) Ankara Üniversitesi Ziraat Fakültesi

\section{Introduction}

Barley is the second major cereal crops after wheat for Turkey in terms of the area sown and production. It occupies 2,720,510 ha (2013) of cultivation area which is $7.08 \%$ of all arable lands. Remains from several excavations indicate that it had been cultivated at several parts of Anatolia namely; Aşıklı Höyük (7500 BC), Çayönü (7200-6500 BC), Can Hasan (6500 BC), Çatal Höyük (60005000 BC) and Erbaba (6000-5000 BC) (Harlan 1995; van Zeist \& de Roller 1995; Karagöz et al 2010). Davis et al (1985) report that following 8 species of genus Hordeum are native to Turkey: $H$. bulbosum L. (perennial), H. violaceuom Boiss. \& Huet (perennial), H. distichon L., H. vulgare L., $H$. spontaneum C. Koch, $H$. marinum Hudson, $H$. murinum L. and $H$. geniculatum All. Apart from above mentioned 8 species, Güner et al (2012) reports $H$. bogdanii Wilensky as a relict species of barley. Gökgöl \& Taşan (1978) mention that durum wheat and barley are the first crops they began to develop at the initial stage of variety development efforts in newly established republic during 1920's. Variety "Karakılçık" is the first released barley cultivar. Today barley is considered to be the fourth most important cereal food crop in the world (Alqudah \& Schnurbusch 2014).

Natural selection through long years of barley cultivation, helped accumulation and development of specific genes against several types of biotic and abiotic stress features such as drought (Toker \& Çağırgan 2010). P M Zhukovsky, commissioned by V I Vavilov collected numerous samples from cultivated crops including 1.168 barley samples (Zhukovsky 1951). Based on several years of observations, Vavilov (1951) claimed that "generally the near east is center of origin and variation for two row barley".
Barley was one of the first domesticated, earliest scattered and most important crops of the farmers of the Middle East (Hawkes 1983; Ceccarelli \& Grando 2000; Gepts 2004; Comadran et al 2009; Badr \& El-Shazly 2012; Hübner et al 2012).

Drought resistance is an important character especially in dry parts of the world. Barley is a drought resistant crop (Ceccarelli \& Grando 2000; Toker et al 2009; Toker \& Çağırgan 2010). Central and South-Eastern part of Turkey, where barley crop is most cultivated, are the driest parts of the country. Due to its drought resistant characteristics, barley is an indispensable crop of such environments.

Barley is a multi-purpose crop. Although it is mainly grown in Turkey for feed and malting industry, several types and forms of barley are also used for other purposes in Turkey and in the world, such as a source of dietary fiber, preparation of food malt, production of ethanol, grazing or mowing for hay as pure stands or in mixture with several crops (Bhatty 1997; Bhatty \& Rossnagel 1997; Bhatty 1999; Asfaw 2000; Özpınar et al 2007; Ghaffaripour et al 2011; Onal-Asci et al 2010; Koçer \& Albayrak 2012). Akar et al (2004) report that the most valuable by product of barley is straw which is used mainly for bedding in developed countries but also for animal feeding in developing and under-developed countries.

Vavilov (1951) hypothesized that center of origin of cultivated plants are the areas where greatest diversity of their wild relatives arises. This theory was confirmed by many other scientists (Gökgöl 1939; Zhukovsky 1951; Harlan 1995). Information on the origin, past and domestication of cultivated plants is important for keeping the diversity as well as developing higher value crops within their 
original region bringing together improved varieties into the farming systems (Badr \& El-Shazly 2012). Landrace populations and wild cereal relatives are important gene sources to broaden the genetic bases of modern cultivars (Özkan et al 2005). Landraces are considered a "genetic record of their prehistoric origins" to be utilized as evidence to investigate early spread of them (Jones et al 2012). Many of the authors agree that wide genetic diversity in landraces provide a source for barley breeders (Asfaw 2000; Ceccarelli \& Grando 2000; Lasa et al 2001; Chabane \& Valkoun 2004; Yahiaoui et al 2008), to guarantee the safety of crop production (Chen et al 2012).

Aims of this study were: (i) to assess the phenotypic diversity in a world population based on agro-morphological traits, (ii) to examine phenotypic similarities between the materials of different origin, (iii) to explore variation sources for future use in barley breeding programs and characterized material for the gene bank.

\section{Material and Methods}

Acollection of 3.500 barley accessions from the stocks of Eskisehir Transition Zone Agricultural Research Institute, providing a broad coverage of Turkish and world material were assembled. The experiment was carried out in Haymana Research Station $\left(39^{\circ}\right.$ $26^{\circ} \mathrm{N}, 32^{\circ} 30^{\prime} \mathrm{N}, 1.210 \mathrm{~m}$ above sea level) in Central Turkey on the Ankara Central Research Institute for Field Crops. The soil is classified as a clay-loam with high lime content ( $\mathrm{pH}$ 7.9) and poor organic matter content $(0.9 \%)$. The mean annual temperature, annual precipitation and relative humidity are $11.8^{\circ} \mathrm{C}, 359$ $\mathrm{mm}$ and 59.7\% respectively. Long-term (1992-2008) climatic conditions of the Research Station is given in Figure 1.

The experiment was conducted for three consecutive years in October of 2005, 2006 and 2007 in 3 meters two rowed unreplicated plots (DeLacy et al 2000) in rainfed conditions. Distances between plants were $10 \mathrm{~cm}$. The following measurements and observation were replicated 5 times on randomly selected plants (IBPGR 1982;
ICARDA 1998): Awn Color (AC) (at maturity, 1white; 3- yellow; 5- brown; 7- red; 9- black); Awn Length (AL) (at maturity, cm); Awn Roughness (AR) (at maturity, 1- rough; 2- smooth); Awn Tip Pigmentation (ATP) (before maturity, 1- with anthocyanin; 2- without anthocyanin); Early Spring Growth (ESG) (before heading, 1- poor; 2- medium; 3- good); Flag Leaf Length (FLL) (after heading, $\mathrm{mm}$ ); Flag Leaf Width (FLW) (after heading, mm); Growth Class (at spring, 1- spring, 2- facultative, 3- winter); Growth Habit (GH) (at heading, 1prostrate; 2- intermediate; 3- erect); Ligule Color (LC) (at heading, 0- without anthocyanin; 1- with anthocyanin); Ligule Length (LL) (after heading, 1- short; 2- long); Number of Days to Heading (DH) (at heading, 1-January 1); Number of Days to Maturity (DM) (at maturity, 1-January 1); Number of Productive Tillers (NPT) (at maturity); Number of Rows (NR) (after heading, 1-6 row; 2- 2 row); Plant Height $(\mathrm{PH})$ (at maturity, from the ground to tip of spike excluding awn); Resistance to Lodging (RL) (at maturity, 1- prostrate; 9- erect); Spike Length (SL) (at maturity, mm); Growth Class (GC) (tillering stage, 1- winter; 3- facultative; 5- spring); Status of Flag Leaf (FLS) (after heading, 1- erect; 2- prostrate; 3- wrinkled); Stem Color ( $\mathrm{SmC}$ ) (at maturity, 1- brown; 4- purple; 5- others); Stipule Color (SC) (at heading, 0- light; 1- medium; 2dark). Only the two rowed accessions have been evaluated. Some of the characteristics such as LC, LL and SC are not directly correlated with yield, but typical for identification of species. That is why they are widely used for identification of plants and characterization of plant genetic resources (IBPGR 1982; Davis et al 1985; ICARDA 1988).

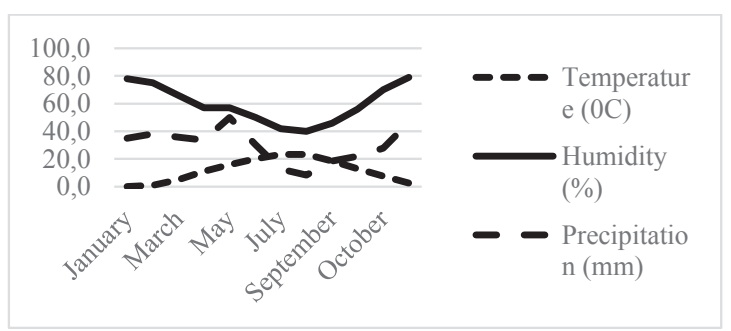

Figure 1-Long-term (1992-2008) climatic conditions of the experiment area 


\section{Results and Discussion}

Mean, standard deviation (SD) and coefficient of variance $(\mathrm{CV})$ were estimated for each set of the figures (Table 1). Cluster analysis based on Euclidian distance was performed to assess the similarities between the barley materials of different origin.

Genetic diversity is the sum of genetic characteristics within any species and genus (Rao $\&$ Hodgkin 2002). Plant breeders need diversity for success of their breeding programs. Magnitude of diversity in a trait of a population is an indication of homogeneity or heterogeneity regarding that particular trait. The standard deviation (SD) is a valuable indicator of diversity (Lasa et al 2001). Coefficient of variation $(\mathrm{CV})$ is also a valuable tool with this respect. Dotlacil et al (2000) considers a $10 \% \mathrm{CV}$ a sign of wide diversity in wheat landraces. Basic statistical information for entire data set is given in Table 1.

Depending on the characters observed, \% CV values of populations ranged from $3.41-72.15 \%$.
Over $50 \%$ of $\mathrm{CV}$ values were calculated with $\mathrm{SC}$ (72.15\%), LC (69.81\%), SmC (65.34), AC (55.82\%) and ESG (50.84\%). The first 4 of these characters are related with color attributes that are generally important for plant identification rather than yield. On the other hand, several research results indicate possible functions of plant anthocyanin such as a chemical defense mechanism against herbivore insects and color may serve as an indication of low quality for larval development (Maskato et al 2014). Anthocyanin may also be protective in preventing damage caused, directly or indirectly by cold temperatures, drought and UV radiation (Gould et al 1995; Chalker-Scott 1999).

Barley varieties with rough awns can puncture the mouth and throat of livestock. Cattles prefer barley varieties with smooth awn (Everson \& Schaller 1955; Park et al 2008). On the other hand, awns contribute significantly to spike photosynthesis and larger awns are possible selection criterion for drought areas (Abera 2009). Total photosynthesis surface of serrated awn is wider than that of the

Table 1- Basic statistical information for entire data set

\begin{tabular}{lrrrrrrrrrrr}
\hline & SD & CV $(\%)$ & $\begin{array}{r}\text { Overall } \\
\text { mean }\end{array}$ & Asia & Europe & America & Africa & Australia & CIMMYT & FAO & Standard \\
\hline $\mathrm{n}$ & 2517 & 2517 & 2517 & 1298 & 484 & 369 & 130 & 21 & 139 & 71 & 5 \\
$\mathrm{AC}$ & 1.39 & 55.82 & 2.5 & 2.7 & 2.3 & 2.3 & 2.1 & 2.8 & 2.5 & 2.3 & 3.0 \\
$\mathrm{AL}$ & 26.09 & 19.90 & 133.1 & 131.5 & 121.9 & 137.1 & 123.7 & 135.2 & 137.2 & 146.5 & 101.4 \\
$\mathrm{AR}$ & 0.43 & 36.13 & 1.1 & 1.1 & 1.1 & 1.2 & 1.1 & 1.0 & 1.1 & 1.2 & 1.0 \\
$\mathrm{ATP}$ & 0.31 & 28.52 & 1.2 & 1.1 & 1.1 & 1.3 & 1.1 & 1.1 & 1.3 & 1.3 & 1.3 \\
$\mathrm{DH}$ & 6.74 & 4.15 & 162.2 & 161.2 & 166.2 & 160.5 & 164.1 & 160.5 & 163.3 & 160.6 & 141.3 \\
$\mathrm{DM}$ & 6.58 & 3.41 & 192.9 & 191.0 & 194.5 & 194.4 & 194.8 & 188.4 & 196.1 & 197.0 & 171.0 \\
ESG & 0.93 & 50.84 & 1.8 & 1.5 & 2.4 & 1.9 & 2.2 & 1.2 & 2.2 & 2.3 & 2.1 \\
FLL & 31.30 & 23.62 & 132.5 & 129.9 & 137.7 & 132.0 & 140.1 & 119.6 & 131.8 & 137.9 & 74.0 \\
FLW & 2.08 & 21.19 & 9.8 & 9.5 & 9.5 & 10.6 & 10.3 & 9.0 & 10.0 & 11.1 & 7.4 \\
GC & 0.64 & 25.04 & 2.6 & 2.5 & 2.7 & 2.5 & 2.6 & 2.3 & 2.8 & 2.6 & 1.0 \\
GH & 0.59 & 34.54 & 1.7 & 1.6 & 1.9 & 1.7 & 1.9 & 1.6 & 1.8 & 1.8 & 1.0 \\
LC & 0.54 & 69.81 & 0.8 & 0.1 & 0.2 & 0.3 & 0.2 & 0.1 & 0.4 & 0.5 & 1.8 \\
LL & 0.39 & 29.30 & 1.3 & 1.3 & 1.2 & 1.5 & 1.2 & 1.3 & 1.4 & 1.4 & 1.3 \\
NPT & 1.97 & 41.48 & 4.8 & 5.1 & 4.1 & 5.0 & 4.3 & 3.9 & 3.9 & 5.5 & 2.2 \\
PH & 15.12 & 20.83 & 72.6 & 75.4 & 66.2 & 76.8 & 68.9 & 73.6 & 63.8 & 77.0 & 60.9 \\
RL & 1.74 & 44.23 & 3.9 & 4.4 & 4.0 & 3.6 & 3.9 & 5.0 & 3.8 & 3.1 & 6.1 \\
SL & 15.68 & 16.85 & 93.0 & 92.0 & 99.4 & 89.0 & 96.9 & 87.1 & 94.2 & 86.8 & 60.4 \\
FLS & 0.74 & 40.62 & 1.8 & 1.8 & 1.8 & 2.1 & 1.7 & 2.3 & 1.4 & 2.0 & 1.5 \\
SmC & 1.44 & 65.34 & 2.2 & 2.4 & 1.8 & 2.4 & 1.9 & 2.0 & 2.4 & 2.4 & 1.0 \\
SC & 0.57 & 72.15 & 0.8 & 0.8 & 0.8 & 0.7 & 0.8 & 0.7 & 0.8 & 0.8 & 2.7 \\
\hline & & & & & & & & & &
\end{tabular}


smooth once. It gives to barbed type of awns an advantage in dry areas to make use of solar radiation. Our barley material consisted mostly of rough awned accessions. Spike size and flag leaves play significant role for yield performance of cereals. Thorne (1965) claimed that due to larger photosynthesis area of ears, barley photosynthesized more than wheat ears, but on the contrary flag leaves of wheat photosynthesized more than those of barley because of their larger leaf area.

Lodging is one of the major constraints limiting the yield and feeding quality of barley (Chen et al 2014). Barley crop suffer frequently from lodging in Turkey (Kandemir 2004). It was reported by Igartua et al (2008) that cultivation of landraces was abandoned in Spain since most of the entries were too tall and prone to lodging. Lodging characteristics showed high degree of diversity with a $\mathrm{CV}$ value of $44.23 \%$ (Table 1). Plant height was one of the highly variable characteristics with a CV value of $20.83 \%$. On the other hand, landraces with taller plant height are reported to yield better in unpredictable rainfall conditions (Acevedo et al 1991; Muhe \& Assefa 2011). Kara (2008) also supports the positive relationship between plant height and barley yield. This factor might be the reason for Turkish farmers to keep cultivating barley landraces especially at low rainfall areas.

Success of growing barley crop in countries with diverging climatic conditions requires a collection of varieties with distinct agronomic characters. It includes winter hardiness for cold areas and resistance to several biotic and abiotic stress conditions (Backes et al 2003; Cockram et al 2007; Yong-Bi \& Horbach 2012). Consequently, several seasonal types have developed in the accession. Majority of the accessions showed spring and facultative type character with a CV value of $25.04 \%$ (Table 1). Barley used to be cultivated as a spring crop in Turkey. It explains why majority of the accessions consisted of spring and facultative types.

Breeders generally pay attention to earliness in their selection program especially in areas with unpredicted rainfall regimes. Although lateness is regarded to secure higher yield by proving a longer maturity period, late accessions do not always mean producing the highest yield at favorable conditions (Loskutov 2010). On the other hand, early varieties are reported to be more resistant to certain diseases (Comeau \& Jedlinski 1987). Among the evaluated characters, the least diversity was found with heading and maturity period.

Initially the entire material was evaluated for their basic characters (Table 1). Comparison of the material of different origin was performed on country basis as well as continent basis. CIMMYT and FAO material were treated separately. Country based evaluation was performed in two stages. First the entire material was treated separately, and the same process was repeated after countries with high degree of similarity were combined and treated in the same group (Karagöz \& Zencirci 2005).

Cluster analysis (Hair et al 1987) was performed on three data sets. First of all, the data set has been re arranged on the basis of countries (Data not presented), continents and international agricultural research centers (Table 1). Clusters formed with barley accessions from different countries (Figure 2 ) indicate that Iraq, Syria, Russia and Afghanistan + Chinese material fell out of the groups formed by the other countries, while rest of the countries formed three distinct groups. Although Syria and Iraq appear to locate out of all the clusters, it may be due to small number of representation of Syrian (13) and Iraqi (6) material, therefore it is not possible to reach a definite judgement about the materials of these two countries. Turkish landraces fell within group of large number of countries namely Japan, Czech Republic + Spain, CIMMYT, USA, Egypt, Argentina, FAO, Austria and Tunisia. It is likely that it is an indication of high degree of material exchange between Turkey, international agricultural research institutes and the above-mentioned countries. Another group is formed by Ethiopia, Australia + France + Hungary + Yugoslavia, The Netherlands + Poland + Switzerland and Denmark + Finland. This may also be the result of large number of materials introduced from Ethiopia. Although materials of some of the nearby countries such as Afghanistan and China; India and Iran; Germany and Sweden; 
Austria, France, Hungary and Yugoslavia; Holland, Poland and Switzerland; Denmark and Finland show high degree of similarity and locate in the same clusters, it is not possible to correlate clustering pattern to geographic origin by agro-morphological characters. Molecular analysis may help better to explain the origin and degree of relationship of the materials of different countries. It is quite sure that long years of adaptation and farmer selection result in development of unique landraces in the countries as stated by Toker \& Çağırgan (2010).

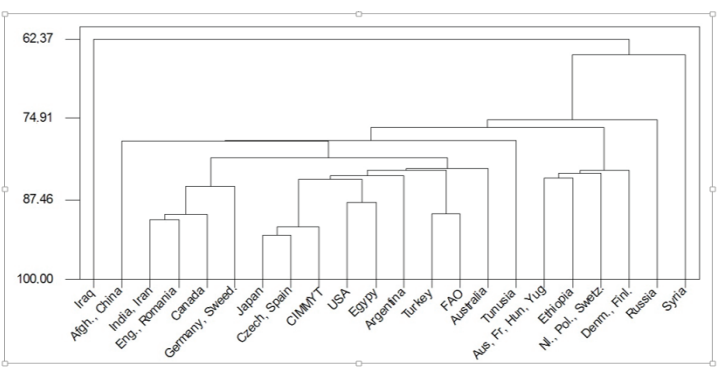

Figure 2- Clusters formed with barley accessions from different countries

Clusters formed with barley accessions from continents, Turkey and two international agricultural research centres is given in Figure 3. This classification lays Africa in a distinct group from rest of the groups. Materials of the two international agricultural research centres reveal high degree of similarity likely because they consist partly of breeding material. Turkish material lies within a group formed by Europe, Asia and America. Australian materials also fall in a distinct group.

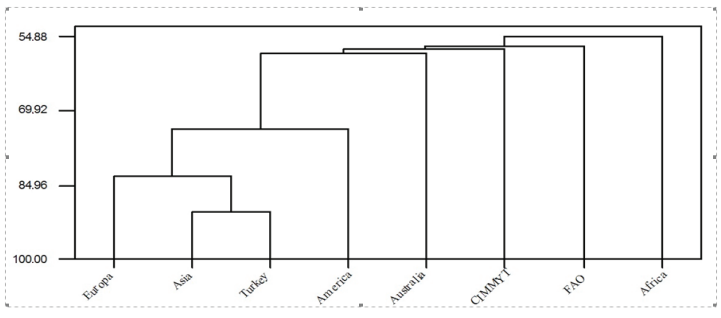

Figure 3- Clusters formed with barley accessions from continents, Turkey and two international agricultural research centres
Comparison of the materials of 5 continents (excluding CIMMYT and FAO material) indicates that Europe and Asia materials show almost $85 \%$ similarities (Figure 4). Highest degree of dissimilarity was observed with the materials of Africa, followed by Australia and America. Recognizable differences of African materials from the others were observed with earlier heading, longer flag leaves, prostrate to intermediate growth habit and shorter ligule length. Almost all the characters of Asian materials fell within the average levels. American materials differed from the other countries mainly by longer ligules. Distinguishing characters of European materials were shorter plant height and awns, later heading, longer spikes and intermediate growth habit. Although Australian materials showed obvious differences by shorter and narrower flag leaves, earlier heading and maturity and erect to semi prostrate flag leaves; low number of accessions (27) did not allow us to make a concrete judgement about Australian material.

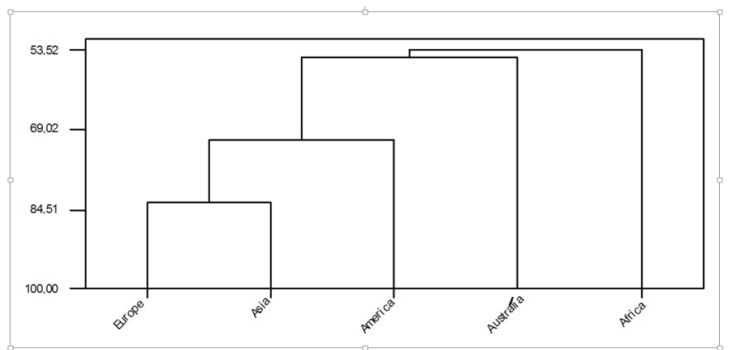

Figure 4- Clusters formed with barley accessions from continents

\section{Conclusions}

Present study revealed that high degree of agromorphological variation is spread between and within the barley germplasm throughout the world. Existing material offers a rich source for barley breeders with this respect to develop improved varieties suitable for various agro-climatic zones of the world. 


\section{Acknowledgements}

This work is part of the "Anadolu Tarımsal Araştırma Enstitüsü'nde Muhafaza Edilen Arpa (Hordeum vulgare L.) Genetik Kaynaklarının Üretimi, Yenilenmesi, Agromorfolojik, Biyokimyasal, Moleküler Tanımlanması ve Arpa Islahında Kullanılması (TOVAG 104O266)" project financially supported by the Turkish Scientific and Technical Research Council (TUBITAK). We express our sincerest gratitude for their support to TUBITAK.

\section{References}

Abera K T (2009). Agronomic evaluation of Ethiopian barley (Hordeum vulgare L.) landrace populations under drought stress conditions in low-rainfall areas of Ethiopia. International Master Programme, Sweedish Biodiversity Center. No: 61, pp. 44

Acevedo E, Craufurd P Q, Austina R B \& Pérez-Marco $P$ (1991). Traits associated with high yield in barley in low-rainfall environments. The Journal of Agricultural Science 116: 23-36

Akar T, Avc1 M \& Düşünceli F (2004). Barley: Post-harvest operations. http://www.fao.org/fileadmin/user_upload/ inpho/docs/Post_Harvest_Compendium_BARLEY. pdf (Accessed date: 12 October, 2014)

Alqudah A M \& Schnurbusch T (2014). Awn primordium to tipping is the most decisive developmental phase for spikelet survival in barley. Functional Plant Biology 41: 424-436

Asfaw Z (2000). The barleys of Ethiopia. In: Brush S B (Ed), Genes in the Field: On Farm Conservation of Crop Diversity. IPGRI, IDRC, Lewis Publishers, pp. 77-108

Backes G, Hatz B, Jahoor A \& Fischbeck G (2003). RFLP diversity within and between major groups of barley in Europe. Plant Breeding 122: 291-299

Badr A \& El-Shazly H (2012). Molecular approaches to origin, ancestry and domestication history of crop plants: Barley and clover as examples. Journal of Genetic Engineering and Biotechnology 10: 1-12

Bhatty R S (1997). Milling of regular and waxy starch hull-less barleys for the production of bran and flour. Cereal Chemistry 74: 693-699

Bhatty R S (1999). The potential of hull-less barley. Cereal Chemistry 76: 589-599
Bhatty R S \& Rossnagel B G (1997). Zero amylase lines of hull-less barley. Cereal Chemistry 74: 190-191

Ceccarelli S \& Grando S (2000). Barley landraces from the Fertile Crescent: A lesson for plant breeders. In: Brush S B (Ed), Genes in the Field: On Farm Conservation of Crop Diversity, IPGRI, IDRC, Lewis Publishers, pp. 51-76

Chabane J C K \& Valkoun J (2004). Characterization of genetic diversity in ICARDA core collection of cultivated barley (Hordeum vulgare L.). Czech Journal of Genetics and Plant Breeding 40: 134-136

Chalker-Scott L (1999). Environmental significance of anthocyanins in plant stress responses. Photochemistry and Photobiology 70(1): 1-9

Chen Z W, Lu R J, Zou L, Du Z Z, Gao R H, He T \& Huang J H (2012). Genetic diversity analysis of barley landraces and cultivars in the Shanghai region of China. Genetics and Molecular Research 11(1): 644-650

Chen W Y, Liu Z M, Deng G B, Pan Z F, Liang J J, Zeng X O, Tashi N M, Long H \& Yu M Q (2014). Genetic relationship between lodging and lodging components in barley (Hordeum vulgare) based on unconditional and conditional quantitative trait locus analyses. Genetics and Molecular Research 13(1): 1909-1925

Cockram J, Jones H, Leigh F J, O'Sullivan D, Powell W, Laurie D A \& Greenland A J (2007). Control of flowering time in temperate cereals: Genes, domestication, and sustainable productivity. Journal of Experimental Botany 58(6): 1231-1244

Comadran J, Russell J R, Thomas W T B, van Eeuwijk F A, Ceccarelli S, Grando S, Baum M, Stanca A M, Pecchioni N, Akar T, Al-Yassin A, Benbelkacem A \& Choumane W (2009). Patterns of genetic diversity and linkage disequilibrium in a highly structured Hordeum vulgare association-mapping population for the Mediterranean basin. Theoretical and Applied Genetics 119(1): 175-187

Comeau A \& Jedlinski H (1987). Successful breeding for barley yellow dwarf resistance or tolerance: A systematic approach related to other agronomic characteristics. In: Burnett P A (Ed), World Perspectives on Barley Yellow Dwarf. CIMMYT, Proceedings of the International Workshop, Italy, pp. 441-451

Davis P H, Mill R R \& Tan K (1985). Flora of Turkey and East Aegean Islands. V9. Edinbourgh Univ. Press, England. pp. 262-269 
DeLacy I H, Skowmand B \& Huerta J (2000). Characterization of Mexican landraces using agronomically useful attributes. Genetics Resources and Crop Evolution 47: 591-602

Dotlacil L, Hermuth J, Stehno Z \& Manev M (2000). Diversity in European winter wheat landraces and obsolete cultivars. Czech Journal of Genetics and Plant Breeding 16: 29-36

Everson E H \& Schaller C W (1955). The genetics of yield differences associated with awn barbing in the barley hybrid (Lion x Atlas ${ }^{10}$ ) x Atlas. Agronomy Journal 47: 276-280

Gepts P (2004). Crop domestication as a long-term selection experiment. Plant Breeding Reviews 24: 1-44

Ghaffaripour S, Karimzadeh R, Mohammadi M, Suq H S, Shefezadeh M K \& Mohammadi N (2011). Karyotypes and evaluation of studies in some genotypes of hullless barley. Turkish Journal of Field Crops 16(2): 245-250

Gould K S , Kuhn D N, Lee D W \& Oberbauer S F (1995). Why leaves are sometimes red. Nature 378: 241-242

Gökgöl M (1939). Türkiye Buğdayları, Tom: II, Yeşilköy Tohum Islah Enstitüsü Yayın No: 14, Tan Matbaas1, İstanbul

Gökgöl M \& Taşan R (1978). Yeşilköy Zirai Araştırma Enstitüsü (Marmara-Trakya Bölge Zirai Araştırma Enstitüsü) 1926-1976. Çelikcilt Matbaası, Istanbul

Güner A, Aslan S, Ekim T, Vural M \& Babaç M T (2012). Türkiye Bitkileri Listesi (Damarl1 Bitkiler). Nezahat Gökyigit Botanik Bahcesi ve Flora Araştırmaları Derneği Yayını. NAMAŞ Yayın, Istanbul

Hair J F Jr, Anderson R E \& Tatham R L (1987). Multivariate data analysis with readings. MacMillan Publ. Co., New York

Harlan J R (1995). Crops and Man. American Society of Agronomy-Crop Science Society of America, pp. 284

Hawkes J G (1983). The Diversity of Crop Plants. Harward University Press, Cambridge, Massachusets

Hübner S, Torsten G, Flavell A, Fridman E, Graner A, Korol A \& Schmid K J (2012). Islands and streams: Clusters and gene flow in wild barley populations from the Levant. Molecular Ecology 21: 1115-1129

IBPGR (1982). Barley Descriptors. International Board for Plant Genetic Resources, Rome, Italy

ICARDA (1998). Barley Germplasm Catalog. Aleppo, Syria
Igartua E, Gracia M P, Lasa J M, Yahiaoui S, Casao C, Molina-Cano J L, Moralejo M, Montaya J L, Ciudad F J, Kopahnke D, Ordon F, Karsai I, Szücs P \& Casas A M (2008). Barley adaptation to Mediterranean conditions: Lessons learned from the Spanish landraces. Proceedings of the $10^{\text {th }}$ International Barley Genetics Symposium (IBGS), 5-10 April, Alexandria, Egypt, pp. 205-214

Jones G, Jones H, Charles M P, Jones M K, Colledge S, Leigh F J, Lister D A, Smith L J M, Powell W \& Brown T A (2012). Phylogeographic analysis of barley DNA as evidence for the spread of Neolithic agriculture through Europe, Journal of Archaeological Science 39: $3230-3238$

Kandemir N (2004). Search for high yielding, lodging resistant barley cultivars with satisfactory straw yields for a fertile production area of Turkey. Pakistan Journal of Biological Sciences 7(6): 971-976

Kara B (2008). Effects of different tillage practices on the trait association in barley. Turkish Journal of Field Crops 13: 32-43

Karagöz A \& Zencirci N (2005). Variation in wheat (Triticum spp.) landraces from different altitudes of three regions of Turkey. Genetic Resources and Crop Evolution 52: 775-785

Karagöz A, Zencirci N, Tan A, Taşkin T, Köksel H, Sürek M, Toker C \& Özbek K (2010). Bitki genetik kaynaklarının korunması ve kullanımı. Türkiye Ziraat Mühendisliğ $i$ VII. Teknik Kongresi. Bildiriler Kitabi (I): 11-15 Ocak, Ankara, s. 155-177

Koçer A \& Albayrak S (2012). Determination of forage yield and quality of pea (Pisum sativum L.) mixtures with oat and barley. Turkish Journal of Field Crops 17(1): 96-99

Lasa J M, Igartua E, Ciudad F J, Codesal P, Garcia E V, Gracia M P, Medina B, Romagosa I, MolinaCano J L \& Montoya J L (2001). Morphological and agronomical diversity patterns in the Spanish barley core collection. Hereditas 135: 217-225

Loskutov I G (2010). Genetic resources and main directions and results of barley and oat breeding in Russia. Agronomy Research 8(3): 673-680

Maskato Y, Talal S, Keasar T \& Gefen E (2014). Red foliage color reliably indicates low host quality and increased metabolic load for development of an herbivorous insect. Arthropod-Plant Interactions 8: 285-292 
Muhe K \& Assefa A (2011). Diversity and agronomic potential of barley (Hordeum vulgare L.) landraces under variable production system in Ethiopia. International Research Journal of Plant Science 2(10): 305-310

Onal-Asci Ö, Acar Z, Basaran U, Ayan İ \& Mut H (2010). Barley companion crop management in red clover establishment. African Journal of Agricultural Research 5(1): 45-54

Özkan H, Kafkas S, Özer M S \& Brandolini A (2005). Genetic relationships among South-East Turkey wild barley populations and sampling strategies of Hordeum spontaneum. Theoretical and Applied Genetics 112(1): 12-20

Özpınar H, Soya H \& Acar Z (2007). The effect of barley ratio (Hordeum vulgare L.) as a companion crop on seed yield and yield components of common vetch (Vicia sativa L.) sown at different rates. $6^{\text {th }}$ International Herbage Seed Conference, GjennestadNorway, 17-20 June, pp. 131-135

Park T I, Han O K, Seo J H, Choi J S, Park K H \& Kim J G (2008). New barley cultivars with improved morphological characteristics for whole crop forage in South Korea. In: Ceccarelli S \& Grando S (Eds) Proceedings of the $10^{\text {th }}$ International Barley Genetics Symposium, 5-10 April 2008, Alexandria, Egypt, pp. 657-665

Rao V R \& Hodgkin T (2002). Genetic diversity and conservation of plant genetic resources. Plant Cell, Tissue and Organ Culture 68: 1-9
Thorne G N (1965). Photosynthesis of ears and flag leaves of wheat and barley. Annals of Botany 29(3): 317-329

Toker C \& Çağırgan M I (2010). Comparison of double haploid barley (Hordeum vulgare L.) lines and native cultivars in semi-arid environment. Turkish Journal of Field Crops 5(1): 1-6

Toker C, Gorham J \& Çağırgan M I (2009). Certain ion accumulations in barley mutants exposed drought and salinity. Turkish Journal of Field Crops 14(2): 162169

van Zeist W \& de Roller G J (1995). Plant remains from Asikli Höyük, a pre-pottery site in Central Anatolia. Vegetation History and Archaeobotany 4: 179-185

Vavilov N I (1951). The Origin, Variation, Immunity and Breeding Cultivated Plants (Translated by: K.S. Chester). Waltham, Mass. Chronica Botanica, New York

Yahiaoui S, Igartua E, Moralejo M, Ramsay L, MolinaCano J L, Ciudad F J, Lasa J M, Gracia M P \& Casas A M (2008). Patterns of genetic and eco-geographical diversity in Spanish barleys. Theoretical and Applied Genetics 116: 271-282

Yong-Bi F \& Horbach C (2012). Genetic diversity in a core subset of wild barley germplasm. Diversity 4: 239-257

Zhukovsky P (1951). Agricultural Structure of Turkey (Translated by: Kıpçak C, Nouruzhan H \& Türkistanlı S). Türkiye Şeker Fabrikası Neşriyatı, No: 20 